\title{
Interactive comment on "A role for Virtual Outcrop Models in Blended Learning: improved 3D thinking, positive perceptions of learning and the potential for greater equality, diversity and inclusivity in geoscience" by Clare E. Bond and Adam J. Cawood
}

Clare E. Bond and Adam J. Cawood

clare.bond@abdn.ac.uk

Received and published: 6 February 2021

Dear Chris Thank you for the positive critique of our paper and for the commented version of the manuscript that you provided. We have tempered the language and amended the title to focus on the tests and associated analysis as you suggested.

Best wishes Clare and Adam 
Interactive comment on Geosci. Commun. Discuss., https://doi.org/10.5194/gc-2020-46, 2020.

GCD

Interactive

comment 